\title{
International Processing INC. A Constructed Mini-case Reflecting Transnational Tax Issues Involving Intellectual Property
}

\author{
William V. Rapp \\ Martin Tuchman School of Management, New Jersey Institute of Technology, United States
}

Copyright@2018 by authors, all rights reserved. Authors agree that this article remains permanently open access under the terms of the Creative Commons Attribution License 4.0 International License

\begin{abstract}
This case study reflects the work done for a large Fortune 500 technology based MNE facing various tax and royalty issues related to the use of its technology by its subsidiaries and affiliates as well as its licensing agreements with other companies in different countries. It also poses a series of $R \& D$ related issues facing the firm including where it should locate a new R\&D facility outside the US. The issues posed in this case arise because each country where the firm does business has a different tax regime but in all cases each government wishes to maximize tax revenues. One way this is accomplished in countries where the subsidiaries are located is by limiting the royalties on technology transfers that subsidiaries pay to their parent firms and thus take as a deductible expense. Conversely the parent firm's government, in this case the US, wishes to maximize its taxes through having the firm's subsidiaries pay "full value" for the technology in the form of higher royalties. This creates a zero-sum game with the firm caught in the middle. The case offers some strategic approaches and ideas the firm can use to manage this situation.
\end{abstract}

Keywords R\&D, Royalties, Taxes

\section{Introduction}

This case study is based on an actual consulting assignment for a technology-based Fortune 500 company. The purpose of the case is to introduce the reader to the influence that taxes and intellectual property rights can play in driving a firm's global R\&D and investment decisions.

\section{Methodology}

We organize our analysis around a description of the company and its international business operations and then focus on the specific FDI [Foreign Direct Investment] and tax issues it faces, especially with respect to taxes paid on its royalty income from its various foreign subsidiaries.

\section{Company}

International Processing Inc. ("IPI") is a synthetic high technology multinational corporation that possesses many of the characteristics of large global companies that produce, license, and use on a worldwide basis technology-based products and services that are subject to intellectual property rights. Such rights can include patents, copyrighted software and trademarks as well as design patents and trade secrets ${ }^{1}$. This is because IPI produces advanced materials that incorporate innovative technologies as well as developing new processes and production software that represent major advances in current practice. It thus needs to protect these innovative developments in order to gain full-value from its large R\&D investments through its own sales or by licensing some technologies to others. It has a whole department composed of lawyers and scientists dedicated to evaluating and enforcing its intellectual property rights on a global basis.

Its current global revenues are in excess of $\$ 15$ billion per year on which it earns after tax about $\$ 1.5$ billion, and it invests about $12 \%$ of sales per year in $R \& D$ to develop new materials, processes, and software. In addition, it works closely with some of its major international customers to develop innovative materials processing solutions that solve their specific problems. It has a physical presence in some twenty countries, and international sales and earnings represent approximately $50 \%$ of the corporation's

1 A general discussion of these Intellectual Property Rights can be found in C. Hill and T. Hult [1]. 
operations but growing $15 \%$ per year compared to domestic sales of $9 \%$. The two largest and most profitable overseas affiliates are in Japan and the EU where they have been for more than thirty-five years. Japan represents about $20 \%$ of overseas sales and the EU about $45 \%$. In the EU they operate in Germany, the UK, France, Italy, the Netherlands, Belgium, Denmark, Sweden, Hungary, and Poland. In Asia they have in addition to Japan operations in India, China, Malaysia, the Philippines, South Korea and Singapore. This represents about another $20 \%$ of overseas sales with Australia, Turkey and Brazil contributing the remaining $15 \%$.

Because of its large financial and product commitment to technology and technology-based competition on a global basis as part of its basic corporate strategy, IPI is constantly working to both access the latest technologies and to protect its own technological interests. At the same time, it has limited resources and cannot produce and market all of the technologies that its researchers and applications engineers develop. For this reason, it is constantly reviewing its technology in terms of its corporate goals, and some of it they license or cross license and others they retain on a proprietary basis for their own use. It also licenses complementary technologies from other companies.

The time and effort, however, it takes to patent, introduce, and manage a new technology in another country, much less several countries, means that IPI approaches its international technology issues within a more considered and integrated framework than its domestic product and technology introductions. Indeed, many technologies that do not succeed in the domestic market are never introduced abroad. Thus, it is only the more successful technologies in the US or elsewhere that migrate on a global basis to exploit additional profit and market opportunities.

This selection process in turn explains the higher profitability of IPI's foreign subsidiaries compared to both the US parent and foreign competitors rather than any special transfer pricing policy for its technology. That is the greater profitability of its overseas operations and the technologies it uses in competing in overseas market is a logical consequence of IPI's technological development and its global competition because it is in its most advanced and successful technologies that it has the greatest competitive edge as compared to local producers. Therefore, these areas attract most of IPI's FDI. ${ }^{2}$

Further, this late introduction sequence allows them under Section 861 to deduct most of their R\&D against their US revenues according to an $80 \% / 20 \%$ split combined with an allocation according to sales. At the same time, the IRS expects the transfer of more successful technologies should lead to higher profits. Royalty rates

2 If one used a Boston Consulting Group four quadrant growth share matrix these international businesses would be treated as Stars [2]. should then be commensurate with this higher income and reflect the oligopolistic nature of IPI's global markets.

IPI's major competitors in most markets for its products and technologies are other MNEs whether their nationality is US, Japanese or European. It is with them that IPI compares itself in terms of profitability on a global basis. This is logical because only such competitors can bring to bear the same resources and internal synergies to compete with IPI and can generate similar cash flows to sustain the rapid competitive technology pace globally. That is, in this industry, the totality of each successful firm is in fact greater than the sum of its parts.

Globally, IPI thus competes in a technically and performance differentiated oligopolistic market. A perfectly competitive world is not IPI's reality.

Indeed, it would probably be extremely difficult for IPI to exist in such a world since they would not be able to compete abroad while at the same time covering the additional costs and risks of operating in a foreign environment against local and other foreign competitors who are just as productive and efficient.

At the same time, they rely on their foreign affiliates to adapt, market, and service their products and technologies in their respective markets. Often these contributions combine with the unique features of the foreign market relative to a specific process or technology to result in unusual profit opportunities. It then becomes difficult to establish whether the technology or the foreign office is responsible for the higher profits than earned elsewhere ${ }^{3}$.

In this regard, IPI faces an economic, business, and tax environment similar to other MNEs which usually exist in industries where technology, size, or other barriers create a global oligopolistic situation similar to that found in the computer, information processing, chemical, petroleum, and materials processing industries. Thus, when IPI considers its relations with its foreign affiliates, and looks at the purpose of sections 482 and 861 of the Tax Code as they relate to the transfer pricing for its products and technology and examines the illustrative examples given by the Service. IPI can see that the IRS is in fact trying to capture some of the oligopolistic returns they believe might have been improperly transferred abroad. Therefore, the very premise of 482 and 861 as they might apply to IPI and its international activities imply oligopolistic competition and differentiated returns.

\subsection{Corporate Development}

In turn, IPI's current situation with respect to taxes and intellectual property rights has evolved from IPI's investment history abroad which has followed a fairly

3 This corresponds to John Dunning's eclectic paradigm or OLI [Ownership, Location and Internationalization] Theory where a firm combines unique local assets with its own proprietary resources so as to achieve a competitive advantage that competitors cannot easily copy or emulate [3], [4]. 
typical pattern for a large internationally based company competing with other large international players in the global marketplace. It first invested abroad about fifty years ago to extend its base products' and technologies' commercial life and to respond to profit opportunities that were as high or higher than what it could find in the US, a BCG Star [5].

In fact, because the basic product development had already been paid for in the US and foreign sales were thus incremental revenue, the returns were very attractive. Yet since IPI did not have a lot of overseas experience at that time, its first activity was to establish a sales and marketing office in Europe and then export product from the US. This was followed quickly by an office in Japan where they developed a close relationship with a local distributor.

Once their foreign sales developed, though, and IPI could justify a local operation, IPI made its first real foreign investment as it added service personnel and limited local manufacturing in order to better adapt its products and technology to the local market. This involved IPI in the actual transfer of some of their product and process technology to its foreign operations and in turn the negotiation of royalty and licensing agreements, often with local governments concerned about tax and foreign exchange effects. The foreign operations then began to take on an economic existence and justification of their own which led to greater local manufacture, $\mathrm{R} \& \mathrm{D}$, and finally even exports and technology licensing by IPI's foreign affiliates to other IPI related entities and to third parties.

Therefore, IPI was in fact able to successfully enter various foreign countries because of its technical, organizational, or other commercial advantages that local firms at that time did not share unless they were also MNEs. If the local firms had fully shared those advantages, could contract for them, or had a superior position, then the profit opportunities would not have been there and the cost, time, and effort for IPI to enter the market would have acted as an effective barrier. No market penetration much less substantial investment and sales growth could have developed.

In addition, IPI would clearly not have been compensated for the higher risks involved in dealing outside the US or in developing the expertise necessary to successfully manage its presence in these other markets in terms of factors like foreign exchange exposure, different customer requirements, or lack of political influence. It was the higher profit opportunity combined with the absence of effective local competition that assisted IPI's foreign market penetration and justified its increased foreign investment and corporate resource commitment on a long-term and strategic basis. These foreign commitments were now starting to pay off in greater international sales and earnings.

\subsection{New Situation}

In the past, IPI's market entry abroad usually took place after the product or technology had had a successful development in the US and the US market was just starting to mature. That is, IPI tended to exploit the US market first where entry was easiest and less costly. Then it exported, and finally invested abroad once the product launch and technology were clearly successful. With this type Vernon Product Cycle evolution [6], as already noted, IPI tended to sell abroad those products in their portfolio where it retained some technical or other advantage. Thus, it generally sold a more limited line of higher profit products in foreign countries than it did in the US. Indeed, the losers or less successful products generally got weeded out domestically and never made it abroad. Therefore, it was almost inevitable that IPI over time was going to report higher earnings overseas than at home.

Further, because most local competition in their products were playing "catch-up", such local competitors generally had lower profits than IPI's foreign subsidiaries since they had to compete on price, bear the high costs of imitation and start-up, and take time to develop comparable quality.

Further as local producers, they had a higher share of mature or non-competitive products in their product portfolio just as IPI did in the US. IPI also had the advantage of an established technical, product, and quality position worldwide as well as the necessary infrastructure, management, and R\&D to produce, market, and improve it.

Therefore, IPI's foreign operations in most countries were able to build experience and market share quickly and to stay more profitable than its foreign counterparts ${ }^{4}$. This was, however, purely the result of the workings of IPI's global competitive environment and corporate decision-making in response to changes in the international product cycle and actual profit opportunities. It was not through some corporate policy to transfer earnings overseas. That is, IPI believed they had fully valued the technology they transferred to their affiliates over the entire life of a product or technology and were receiving good returns both in the form of profits (dividends) and royalties set according to a companywide norm.

Before entering a country, IPI management as in Japan had frequently had extensive negotiations with local governments before the latter acceded to the proposed royalty rate. However, the fact that IPI charged one common rate for all their technologies globally made these negotiations much easier.

Also, by establishing their global presence, IPI had prevented the development of potential new competitors or the strengthening of existing ones, thus protecting the company's long-term survival and profitability. In this

4 Experience as first identified by the Boston Consulting Group is the total amount of a product ever produced and is directly related to a reduction in real unit costs in a particular country. For IPI a doubling of experience in a given country usually resulted in a $20 \%$ reduction in real unit costs [7] and improved market share. Having more experience is why market share is a key metric especially in high growth markets where share and experience is more easily gained by the early leaders [8]. 
manner IPI seems to have received value just from establishing a prior market position via foreign investment. In fact, profit comparisons of IPI's affiliates with local foreign competitors in almost all countries show superior results for IPI of at least 3 to $4 \%$ on sales.

One reason for this advantage is that IPI can manage its various manufacturing plants globally in order to achieve certain operating efficiencies. This is a function provided by its multiple overseas affiliates that is a valuable part of its global reach that would otherwise be unavailable to the corporation. In turn, an affiliate sometimes provides unique access to certain situations such as particularly demanding and technically sophisticated customers or certain types of technology in which that country is preeminent. This situation has clearly helped IPI since it has enabled it to use that knowledge and experience to sell that technology or solution to other companies globally.

This type of strategic orientation is something IPI's management has become more aware of due to Michael Porter's Competitive Advantage of Nations [9]. The intangibles provided by IPI's overseas subsidiaries on a global basis have therefore gotten bigger and more important over time and are likely to get even larger. IPI now therefore often launches new products or technologies abroad at the same time it introduces them in the US, particularly in the case of Japan and Germany. It is also currently considering launching a major new technology in these countries prior to its introduction in the US.

This is because it has diversified its R\&D globally in order to keep abreast of competitors' developments and to work better with its major foreign customers. Therefore, while their primary R\&D center is in the US, they also have centers in Japan and Germany. These centers both develop their own technology and improve or modify for local use the technology developed in the US. In addition, IPI's sales and applications engineers located in each of their twenty overseas affiliates are constantly working with their customers in those countries on new solutions. These often result in improved products and services as well as new applications for existing technology.

Some of these developments are subsequently licensed by other affiliates or to the parent for use by their customers. However, the parent has a blanket license entitling it to receive any technologies developed by any affiliate on a royalty free basis since all of IPI's business is considered to have evolved from the basic technologies developed and distributed initially to the affiliates. This is not true for the affiliates, though, which must pay their brother and sister companies for their intellectual efforts according to the established corporate rate of $12 \%$ for tangible technology, i.e. incorporated into products, and $30 \%$ for intangibles such as processes and software.

As noted above, IPI has an active patent (new products and processes) and copyright (software) group whose responsibilities include filing for intellectual property protection and the monitoring of competitors. The intellectual property group also has a section that handles third party licensing of new technology both to and from others.

In fact, over a period of years, given IPI's very active and aggressive $R \& D$ investments, it has succeeded in building a technology portfolio that returns about $\$ 1.6$ billion in net royalties a year of which about $\$ 750$ million come from third parties and $\$ 850$ million from affiliates, the latter of which washes out in consolidation.

The revenue from affiliates in turn is $\$ 350$ million from tangible and $\$ 500$ million from intangible property with the former growing at $10 \%$ and the latter at $20 \%$ per annum respectively, reflecting IPI's increasing emphasis on process and software $R \& D$.

\subsection{Review Questions and Further Discussion of IPI's International Business Development}

- Is IPI's entry into international business fairly typical of older US MNEs?

- Which trade and FDI theories seem applicable to IPI's development: Vernon's International Product Cycle [10], Knickerbocker's Oligopolistic FDI [11], Porter's Diamond [12], New trade Theory [13], Absolute Advantage [14], Comparative Advantage [14], Heckscher-Olin [15], Leontieff Paradox [16]? ${ }^{5}$

- $\quad$ Should strategy and competitiveness considerations come first and then tax or is tax part of the overall strategy mix?

- What strategy considerations should be most important to IPI's site selection for the new special materials R\&D center?

- If a key scientist is only available in Germany would tax considerations matter? If a critical material can only be made in Japan would tax considerations matter?

\subsection{Royalties and Transnational Taxes}

Just as IPI has a group dedicated to managing its technology and intellectual property it has a tax group that is concerned about the licensing arrangements for proprietary technology between affiliates and the $\$ 350$ million in actual payments.

This is because when IPI's US parent provides technology to its foreign subsidiary it must charge the foreign affiliate a licensing fee. Even if they chose not to do so, the IRS [US Internal Revenue Service] would insist on it. The rationale is that for a high technology company such as IPI, a technology contribution to its foreign affiliate represents a capital investment on which IPI should be

5 A discussion of these theories can be found in any standard international business textbook such as C. W. Hill, G. T. Hult, International Business, Competing in the Global Market Place [17]. 
earning a return in the form of a royalty in the same way as if they had made a cash investment or a loan. This concept views IPI's technology as an asset that will enable the affiliate to earn more money since their customers will pay for it. Therefore, a return should be paid to the parent [IPI] on the technology just as the subsidiary would pay interest or a dividend on a loan or equity investment.

The IRS is also concerned that the royalty charged be appropriate. Therefore, just as the IRS pays close attention to intercompany interest charges, dividends, or cost of goods sold, including transfer pricing, it carefully monitors how IPI values the technology and establishes the appropriate royalty rate. This process is relatively straightforward in the case of licensing technology either from or to third parties because this is basically an arms-length transaction in the market.

Therefore, to establish the proper rate between related parties under section 482 of the US tax code, the proposed easy and sensible solution is for IPI to then just find a similar market-based transaction to use as a proxy. This will certainly work with IPI's affiliates to the extent that IPI is licensing its generic technology that it licenses to everyone else.

The practical problem facing IPI, though, is that the technology that really makes IPI's affiliates distinctive, competitive, and profitable in the global markets where it competes is the proprietary technology that by definition is not licensed and is most likely to be more valuable than that which is licensed. The question then is how much more valuable and how do you value this technology, especially at the time it is first introduced and its true potential is essentially unknown?

In order to deal with this issue, to simplify its worldwide licensing task, and to not bias its resource allocation decisions, IPI for many years has been charging its affiliates a flat rate of $12 \%$ of sales on technology that is incorporated into a tangible or physical product and 30\% on processes and software where there is no product that already includes its own profit margin as in the case of tangibles. These rates have in turn been grandfathered in Japan and some other countries due to the technology licensing arrangements IPI negotiated with these governments when they entered the Japanese and other markets in the late 1960s.

However, the IRS is now challenging this approach and is requiring IPI to justify its royalty rate according to the facts and circumstances surrounding each technology in each country and to attribute or split the profit due the parent or the affiliate respectively. Given the number of process, technologies, and proprietary software programs, as well as the numerous contributions made over the years by various affiliates, plus the wide swings in economic use and performance in each country, the differing rates of technological evolution, and the occurrence of chance events affecting technologies, this new requirement seems to be a monumental and perhaps unworkable task.
It could also involve IPI in endless debates and negotiations with various tax regimes as it seeks to change under IRS pressure the already established and accepted rates that in turn affect IPI's reported income and tax in these countries, reflecting the zero-sum game reality between different countries over taxes as they apply to large MNEs. This contentious and controversial issue is currently reflected in the EU's decision to apply a 3\% tax to the revenue streams in Europe of firms such as Google and Facebook.

More particularly, IPI as a whole has recently benefited from some major developments in its Japanese R\&D center for which they have not had to pay any royalties given their historical arrangements with the Japanese government.

However, if they have to change their royalty rate with their Japanese affiliate to accommodate IRS requirements, the Japanese government could use this situation as an excuse to renegotiate the overall royalty arrangement to properly reflect its Japanese operation's technical contribution to IPI over the years.

Other countries could then use this change as precedent and pretext to force similar negotiations recognizing their countries' affiliates' contributions too. While this whole process would clearly be onerous and time consuming for IPI, it is not clear whether the end result would actually lead to more or less royalty income to the US parent and thus to the IRS. This is because up until now IPI has been benefiting from a one-way royalty flow due to the parent's free licensing rights under the existing royalty agreements.

\section{R\&D Investment}

While these are issues that IPI is presently having to grapple with daily as it licenses its proprietary technology to its affiliates, licenses from them, and they license to each other, IPI has a more immediate problem as well. That is, it believes there are some important emerging coating technologies in advanced materials processing for which they need to perform basic research.

IPI is therefore planning to invest $\$ 300$ million in expanding their R\&D facilities and is building a specialized research team. This research could provide the foundation for a new multibillion-dollar business. The question is where to locate it. While historically IPI would have broken ground immediately in the US, there are business arguments for looking overseas.

Some of these coatings have significant uses in the electronics industry where being in Japan near major customers and the customers' technology base would be advantageous. Also, if they locate in certain depressed areas, various Japanese government incentives are available. However, some of the best chemical and optical scientists are in Germany, and there are major incentives available there too if they were to locate in East Germany. They could also access inexpensive Russian software 
engineers.

A key factor in the decision, though, is also likely to be the tax treatment of the royalty income that will flow to the US, German, or Japanese operation over a twenty-year period as the technology expands and develops. This is because the tax burden will affect the total cash available to the company for reinvestment as well as the overall after-tax rate of return to the shareholders.

From a transnational tax viewpoint questions about the likely valuation and tax treatment of IPI's new technology over an extended time horizon is therefore critical to IPI. If the $R \& D$ and patents are US-based, such royalties are booked as income in the United States and as an expense to the affiliates. It is therefore taxed as income in the US, which is why the IRS wishes to maximize its flow.

Conversely, if it is a deduction for the foreign affiliate, it represents a revenue loss for the foreign taxing agency. Nor is IPI indifferent to this process, depending on whether the tax rate is higher or lower in the foreign country than in the US. So while corporate rates in Japan and Germany are usually much higher than the US, this could be significantly mitigated by the cheap government financing, the tax holidays, and other concessions currently available. In addition, unlike the IRS, these governments may be willing to lock in the terms and conditions with respect to setting the long-term royalty rates.

This would then allow IPI to avoid complicating its valuation problem given the fact that both the IRS and the foreign tax agencies recognize that the foreign affiliate may add value to the existing technology. Therefore, some return will be due to their efforts and that should be compensated accordingly. This has been especially true for IPI in Japan and Germany where IPI's R\&D centers have developed several of their own innovative technologies that they have then licensed to other parts of IPI.

\subsection{Panel Analysis and Recommendations}

A basic question for IPI is thus what role the possible tax treatment of royalty income should play in their location decision. Given this potential importance of transnational tax issues to the location decision, a panel of experts has been formed to advise IPI's top management as to what their location and negotiating recommendations should be from a tax standpoint.

The panel is thus in a position to suggest ways of improving the existing template in this de novo situation. At the same time, IPI has existing licensing and technology arrangements with its affiliates and continues to produce new technologies and software for these businesses at a rapid rate. IPI will therefore also need the panel's expert advice on how from a tax standpoint it should organize itself to best deal with its existing proprietary technology transfers and royalty stream payments, given that developing, managing and licensing its technology has now become an IPI Core Competency [18]. ${ }^{6}$

That is, using IPI's situation as a springboard and an illustration of the tax complexities surrounding the payment streams for intellectual property use across borders, the panel will address how transnational tax issues affect IPI's intellectual property flows and development. Sections 482 and 861 hit royalty income and technology exchange between affiliated entities particularly hard but their impact will vary by country. The possible effects on the location and the pursuit of $R \& D$ are therefore especially critical.

Some important issues on transnational tax the panel experts will cover in their review of IPI's situation are listed below. But based on their experience they may raise other issues too. However, as they proceed in their analysis and assessment, a fuller appreciation will more clearly emerge of the size, complexity, and importance of the problems that arise when various governments strive to either tax or minimize royalty income depending on their situation. On a worldwide aggregate basis, billions of dollars are involved.

\subsection{Initial Issues List}

There are difficulties in valuing proprietary intangible technology, especially software, so that the method of valuation is both acceptable to all the relevant taxing authorities and the company does not pay any excess tax as it transfers or licenses such property to offshore affiliates. IPI's management would like to resolve these issues in advance in the new expanded R\&D location and to work towards a more realistic solution in their existing arrangements too.

IPI needs a commonalty among national taxing agencies due to its technology transfers among multiple countries combined with the additions (modifications, research, etc.) by affiliates continuously occurring in different countries that may contribute to the overall technology available to IPI globally. This commonalty would be best served by the acceptance of a common rate for all such IPI property if it could be justified or at least for broad classes of technology related property by type and/or industry.

IPI also needs relief from the IRS's 1986 "look back" provisions or the twenty-twenty tax hindsight by the tax authorities when particular technologies either gain or lose value over time due to income variations that result from wide acceptance, technological obsolescence, or some other event unforeseen at the time the technology was first licensed.

6 A core competency is a skill or benefit that covers a range of businesses or functional areas and gives a firm a competitive advantage over rivals [18]. 
Being allowed to set and fix a royalty at the beginning within specific parameters would permit IPI to transfer technology without worrying about future perceived changes in the "value" of a particular technology compared to the actual "uncertainty" at the time of development and initial licensing.

Further, it may be that while the IRS is focusing on capturing "extra" revenues from IPI's unanticipated blockbusters or super products that in fact these are largely offset by the products whose revenues do not meet IPI's initial expectations. Therefore, by establishing an average rate over a period of time that included the expectation of a certain number of super successes, IPI could both simplify their royalty procedures and meet the IRS requirements.

IPI would prefer to avoid having tax considerations play a role in the global allocation of its $R \& D$ resources and to instead put research in the best place for the science or in terms of developing and improving the technology. However, current regulations and tax rates affecting licensing and royalty income could impact IPI's decision on where it should expand its R\&D facilities and locate its new advanced materials processing team. If this affects other MNEs equally, this also has implications for those nations’ R\&D base.

Given that IPI is producing hundreds of new technologies a year and has an intellectual property portfolio perhaps ten times that, IPI also faces serious computational and valuation difficulties if it is expected by the tax agencies to value each technology, process, or piece of software separately as an individual item on an annual basis instead of establishing or developing values for various classes or all intangibles together based on corporate or industry experience and fixing them at this historical rate over the life of their licenses.

Projecting and discounting highly probabilistic cash flows for all these different technologies is neither practical nor likely to approximate any future reality. In turn, waiting for events to simply unfold is unworkable as well. Therefore, the experts must advise IPI and make concrete recommendations on how it should handle these issues under the IRS 482 or 861 regulations, and in tum make some predictions on how the other two major tax regimes, Germany and Japan, might react under different circumstances?

On the surface, evaluating the merits of IPI's uniform across the board internal royalty system compared to a profit split or other proposals, it seems the easiest to administer both for IPI and between countries. It is also the lowest cost approach and the least likely to raise political problems since everyone is treated more or less equally. However, can it be justified on theoretical as well as practical grounds so that IPI could persuade the IRS and other tax authorities and the IRS or other tax authorities could also justify it to Congress or other legislatures hungry for more revenues?

Given that IPI has been able to internalize certain externalities that help it compete in the international marketplace, it would not seem to make sense to try to disaggregate IPI into its corporate components for tax purposes. Indeed, if one tries, one is going to end up with a residual that must be allocated among the parts. Therefore, if an across the board royalty rate solution seems impossible, would the panel of experts recommend a profit split approach instead as the next most logical alternative, and if so, how does the panel suggest IPI implement it?

For example, since the profit split analysis applies only to self-developed intangibles and must be elected in advance, would the panel suggest that IPI elect the profit split method? This choice does present difficulties for IPI because to manage the process after any new regulations or taxes are implemented, IPI needs to begin now and will probably have to aggregate for tax purposes some of its foreign operations. In tum, they must prove to the IRS and other tax authorities that their aggregation rule works completely and that the profit split is accurate in terms of the investment or contribution at risk by each entity.

Otherwise, IPI could face as much as $40 \%$ penalties on top of additional tax and interest. Thus, detailed record keeping is necessary and extremely important, though also potentially very costly.

In sum, IPI needs the panel's advice on how a system could be established to do this simply and efficiently. This will be especially critical in those cases involving spectacular successes in specific countries where the contribution by IPI's local operations are arguably large, such as in Japan. Further, the panel should explain how to handle those cases where the intangibles have been licensed from third parties, but IPI has then made its own improvements and changes domestically and overseas.

As either a complementary or separate approach to this issue, the panel needs to address whether it would recommend that IPI negotiate an APA (Advanced Pricing Agreement) with the IRS, Japan, Germany, Canada, and perhaps Australia. Though this agreement would probably last only five years and would be conditional on the facts and circumstances of IPI's situation remaining roughly the same, it would buy time, would establish a precedent and could form the basis for negotiations with other countries.

If the agreed conditions primarily specified meeting an expected average revenue benefit, anticipating the emergence of some surprises, blockbusters or failures, this could accomplish several of IPI's technology related tax goals.

\section{Concluding Review ${ }^{7}$}

7 Some tax, FDI and strategy issues related to this consulting assignment include: 1) Are tax issues essentially a matter of negotiation with governments? 2) Do recent mergers in Pharmaceutical Industry between US firms and EU firms in low tax countries make sense? 3) Is Apple's 
The main issue facing the panel of experts is what kind of Intellectual Property investment theory should IPI present to the IRS and other tax authorities to continue its simple global royalty payments and current tax treatment including its application to the new R\&D Center?

The panel believes that given the normal competitive and management evolution of IPI outlined above, which is quite similar to other US MNEs, an IRS position that attributes "higher than normal profits" differentials abroad to improper transfer pricing for technology instead of the natural result of the competitive selection of products for sale in foreign markets seems inappropriate.

Indeed, the panel feels the IRS may be missing the reality that it is in fact the foreign competitors' profits which are lower than normal rather than the other way around. Local foreign competitors are willing to accept this situation so as to get into a new technology and market or defend existing markets and customers against a powerful foreign MNE such as IPI. They may even get government support for this competitive development strategy.

Since the IRS approach to revisiting global royalty rates clearly affects IPI's overseas subsidiaries' profitability, it raises a budgetary zero-sum game among the taxing authorities in the countries where IPI operates. Given IPI's relative size and visibility in these countries, serious and complex tax treaty negotiations could easily follow.

The panel doubts whether the IRS has thought through the implications of its revised policies for its relations with these other taxing agencies and thus should be open to persuasion given the right economic explanation.

In this regard the expert panel had two major recommendations on how IPI should approach the IRS to address these issues so as to meet the IRS's objectives of raising revenues and preventing royalty rate abuse but without forcing IPI to locate its new R\&D facility merely for tax reasons or creating tax treaty problems with other governments.

The first recommendation the panel outlined would be for IPI to enter into APAs with the governments in its major markets as explained above. Indeed, many of IPI's global competitors have pursued this route given similar tax issues and this would give IPI some precedents from which it could negotiate.

The second recommendation that IPI ultimately followed and that proved a successful argument with the IRS at least in the case of IPI was a business portfolio approach to its technology investments. Under this argument, IPI would explain that it operates its technology

approach to international tax treatment similar to IPI's? [19] 4) Do MNEs have an obligation to pay taxes even if they can avoid them? 5) What other taxes do MNEs pay besides corporate income taxes? 6) Would it make sense for all members of the WTO to charge a flat $10 \%$ withholding tax on all royalty payments with the receiving country giving credit against any income taxes due? 7) How much influence should taxes have on strategy decisions? Does this depend on the amount of the tax or is it only a matter of the net present value of the discounted cash flow to the parent after tax? development and $R \& D$ as a business on which it expects an overall rate of return similar to the corporate hurdle rate it applies to all its investments and business activities, including foreign affiliates.

Thus, IPI does not look at any one specific technology's return but rather it manages the return on all its technology investments from a portfolio viewpoint where it has a multiplicity of technologies each composed of a different income stream. Revenue to each can include but is not limited to higher profit margins on new processes or products as well as licensing fees and royalties. It also offsets losses on less or unsuccessful initiatives against the technology portfolio's income stream along with the expenses related to R\&D, licensing management, and the intellectual property group.

Given that this portfolio approach to developing and managing its technology as a business was accepted by the IRS, where IPI should locate its new materials R\&D Center becomes dependent on other business considerations such as available personnel and important customers or other locally based incentives. There could also be beneficial competitive externalities.

This result could occur because the Cliftama Administration has submitted a major tax revision proposal that will affect the treatment of royalties from both related and unrelated parties in terms of being passive or active. A possible net effect of this proposal could be to penalize firms that are successful in increasing their royalty incomes, a "stick and stick" approach that appears somewhat contradictory.

However, by following the panel's recommendation to treat its technology development as a business that manages a portfolio of technology assets, all IPI's technology related activities should now be considered active. IPI should thus avoid the implications of the new royalty tax regime if it were adopted but that may trap other MNEs. Further royalty related taxes should now have less effect on IPI's future R\&D decisions. This situation will work as well to have IPI in fact treat its technology portfolio and its development as a business and core competency that gives it an advantage over rival firms that those competitors will find difficult to match.

\section{REFERENCES}

[1] C. W. Hill, G. T. Hult, International Business, Competing In The Global Marketplace, 11th ed., McGraw Hill, NY, 2016

[2] C. Stern, M. Deimler, Boston Consulting Group On Strategy, Harvard Business Publishing, Boston, MA 2006

[3] J. Dunning, Toward an Eclectic Theory of International Production: Some Empirical Tests, Journal Of International Business Studies, 11 (1), 9-31. 1979

[4] J. Dunning, The eclectic paradigm as an envelope for 
economic and business theories of MNE activity, International Business Review, 9, 163-190. 2000

[5] C. Stern, M. Deimler, Boston Consulting Group On Strategy, Harvard Business Publishing, Boston, MA 2006

[6] R. Vernon, International Investment and International Trade in the Product Cycle, the Quarterly Journal of Economics, Volume 80, Issue 2, 190-207. 1966

[7] C. Stern, M. Deimler, Boston Consulting Group On Strategy, Harvard Business Publishing, Boston, MA 2006

[8] W. Rapp, Strategy Formulation and International Competition, Columbia Journal of World Business, Vol. VIII, No. 2, p 98-112. 1973

[9] M. Porter, The Competitive Advantage Of Nations, The Free Press, MA, 1998

[10] R. Vernon, International Investment and International Trade in the Product Cycle The Quarterly Journal of Economics, Volume 80, Issue 2, 190-207. 1966

[11] F. Knickerbocher, Oligopolistic Reaction and Multinational Enterprise, Harvard University Press, Cambridge, MA 1973

[12] M. Porter, The Competitive Advantage Of Nations, The Free Press, MA, 1998

[13] P. Krugman, Increasing returns, monopolistic competition, and international trade, Journal of International Economics, Volume 9, Issue 4, 469-479. 1979

[14] P. Krugman, M. Obstfeld, International Economics: Theory and Policy, Pearson, Boston, 1997.

[15] E. F. Heckscher, B. Olin, Heckscher-Olin Model, https://www.investopedia.com/terms/h/heckscherohlin-mod el.asp

[16] W. Leontief, Domestic Production and Foreign Trade - The American Capital Position Reexamined, Economia Internazionale, (VII), 1. 1954

[17] C. W. Hill, G. T. Hult, International Business, Competing In The Global Marketplace, 11th ed., McGraw Hill, NY, 2016

[18] C. Prahalad, the Core Competence of the Corporation, Harvard Business School Reprint, Boston, MA. 1990

[19] C. Duhigg, D. Kocieniewski, How Apple Sidesteps Billions in Taxes, NY Times, 2012. 